\title{
Profesionalitas Pelatih Dalam Pengembangan Kualitas Paduan Suara Nine's Voice di SMA Negeri 9 Manado
}

\author{
${ }^{1}$ Billy Muskitta, ${ }^{2}$ Markus Wibowo, ${ }^{3}$ Erwin Sianturi \\ ${ }^{1}$ Mahasiswa Program Studi Pendidkan Musik Gereja IAKN Manado, ${ }^{2}$ Dosen \\ Program Studi Musik Gereja IAKN Manado, ${ }^{3}$ Dosen Program Studi Pendidikan \\ Musik Gereja IAKN Manado \\ 1billymuskitta28@gmail.com, 2wibowomarkus986@gmail.com, 3esianturi@iakn- \\ manado.ac.id
}

\begin{abstract}
Abstrak
Nine's Voice merupakan salah satu kelompok paduan suara sekolah di Sulawesi Utara yang bertempat di SMA Negeri 9 Manado. Banyak prestasi yang sudah diraih oleh paduan suara ini baik nasional maupun internasional. Kesuksesan tersebut membuat peneliti tertarik melihat bagaimana kepelatihan yang dimiliki oleh Nine's Voice. Berdasarkan hal tersebut maka peneliti merumuskan dua masalah pada penelitian ini yaitu, apa saja yang menjadi kriteria dari seoarang pelatih yang profesional dan bagaimana peran dari seorang pelatih yang professional. Penelitian ini merupakan penelitian kualitatif deskriptif. Dari hasil penelitian menunjukan, ada tiga aspek yang dimiliki oleh seorang pelatih yang profesional yang pertama yaitu, Skill (keterampilan), Knowlegde (pengetahuan), dan Attitude (Sikap). Peran Seorang pelatih bukan saja hanya berfungsi sebagai pengajar namun pelatih yang profesional memliki peran sebagai pengambil keputusan, pembentuk karakter kelompok, menciptakan budaya kelompok dan sebagai pengelola paduan suara
\end{abstract}

Kata Kunci : Nine's Voice Choir, Profesionalitas, Pelatih, Paduan Suara

\begin{abstract}
Nine's Voice is a school choir group in North Sulawesi which is located at SMA Negeri 9 Manado. Many achievements have been made by this choir, both nationally and internationally. This success made researchers interested in seeing Nine's Voice coaching. Based on this, the researcher formulated two problems in this study, namely, what are the criteria for a professional coach and what is the role of a professional trainer. This research is a descriptive qualitative research. The research results show that there are three aspects possessed by a professional trainer. The first is Skill (skills), Knowlegde (knowledge), and Attitude (Attitude). The role of a trainer not only serves as a teacher but a professional trainer has a role as a decision maker, shaping the character of the group, creating a group culture and managing a choir.
\end{abstract}

Keywords: Nine's Voice Choir, Professionalism, Coach, Choir 


\section{Pendahuluan}

Paduan suara merupakan
salah satu jenis musik vokal yang
berkembang sampai sekarang ini.
Perkembangan paduan suara
sangatlah pesat, bukan hanya di
lingkungan gereja tetapi juga
dilingkungan sekolah dan bahkan di
lingkungan instansi tertentu.

Perkembangan ini juga diiringi dengan kualitas yang sangat baik.

Kelompok paduan suara juga dikembangkan di sekolah-sekolah. kegiatan paduan suara di sekolah bertujuan untuk mengembangkan minat dan bakat siswa dalam bidang seni serta memberikan pengalaman .sekolah yang berkembang dan memiliki banyak prestasi tingkat nasional bahkan internasional adalah paduan suara di SMA Negeri 9 Manado yang dikenal dengan nama Nine's Voice. Paduan suara ini juga aktif di berbagai kegiatan kesenian baik dalam lingkungan sekolah maupun di luar lingkungan sekolah. Selain itu paduan suara ini juga aktif mengadakan konser setiap tahunnya untuk menumbuhkan budaya paduan suara di Sulawesi Utara.

Kualitas paduan suara ini banyak mengalami kemajuan dan meraih berbagai prestasi tentunya tidak lepas dari campur tangan seorang pelatih paduan suara. Tidak bisa dipungkiri, terbentuknya sebuah paduan suara yang berkualitas tentunya harus melewati beberapa proses, baik proses latihan maupun proses dalam mengatur atau mengolah (manajemen) kelompok paduan suara. Didalam proses pelatihan ada beberapa hal yang harus dilatih diantaranya, melatih kedisiplinan, melatih sikap solidaritas antar sesama anggota paduan suara dan tentunya melatih kemampuan (skill) dari anggota paduan suara. Semua hal diatas akan terlaksana dengan baik oleh arahan dari seorang pelatih yang tentunya mempunyai keahlian dibidangnya atau seorang pelatih yang profesional. "Seorang pelatih adalah tokoh sentral dalam proses latihan, seorang pelatih juga harus memiliki kreatifitas dan imajinasi yang kuat sehingga kualitas latihan semakin meningkat. Toko sentral tersebut harus memiliki ciri-ciri antara lain, kepribadian, kemampuan fisik, keterampilan, kesegaran jasmani, pengetahuan dan pola pikir ilmiah, 
pengalaman, human relation dan kerja sama serta kreatifitas. ${ }^{1}$

Fenomena yang terjadi sekarang ini adalah bahwa seorang pelatih sudah dikatakan profesional hanya berdasarkan pengakuan dari masyarakat, dilihat dari pengalaman mereka dalam bidang paduan suara. Pengalaman mereka dalam membawa sebuah paduan suara mengikuti berbagai lomba baik ditingkat nasional bahkan internasional dan dari berbagai prestasi yang berhasil diraih oleh kelompok paduan suara tersebut.

Selain itu, ada juga seorang pelatih yang hanya meneruskan suatu paduan suara yang sudah ada, dengan kata lain seorang pelatih hanya meneruskan atau melatih suatu paduan suara yang sudah diisi oleh penyanyi-penyanyi yang berkualitas atau penyanyi-penyanyi yang sudah memiliki kemampuan olah vokal yang baik. Tetapi bukan hanya itu saja, ada beberapa hal yang juga harus diperhatikan untuk seorang pelatih yang profesional. Hal ini juga didukung

\footnotetext{
${ }^{1}$ Cessna Kurniawan, "Peran Pelatih Dalam Pelatihan Paduan Suara Dengan Menggunakan Pendekatan Secara Psikologi Di Paduan Suara Voice Of Conservation(VOC) Universitas Negeri Semarang", skripsi yang diterbitkan (Semarang: , Jurusan Seni Drama, Tari dan Musik, Fakultas Bahasa dan Seni, UNNES, 2018), h. 22
}

oleh pendapat dari Ali mudlofir bahwa ada tiga aspek dari seorang yang profesional yaitu skill, knowledge dan attitude. $^{2}$ Selain itu seorang pelatih harus memiliki jiwa kepemimpinan yang sangat tinggi dalam memimpin sebuah paduan suara. Hal ini didukung oleh pendapat dari M. Karyadi mengenai kepemimpinan adalah suatu seni kemampuan untuk mempengaruhi perilaku manusia dan kemampuan untuk mengendalikan orang-orang dalam organisasi agar supaya mereka sesuai perilaku yang diinginkan oleh pemimpin organisasi". ${ }^{3}$ Dalam hal ini seorang pelatih harus mengerti dan paham akan karakter setiap anggota paduan suara agar apa yang diberikan dalam proses latihan dapat dimengerti dan sesuai dengan tujuan yang akan dicapai.

Berdasarkan uraian diatas, maka penelitian ini bertujuan untuk menjelaskan kriteria dan peran dari seorang pelatih yang profesional sebagai pondasi yang kuat dalam mendorong perkembangan dan

\footnotetext{
2 Ali Mudlofir, Pendidik Profesional, (Jakarta: PT RajaGrafindo Persada 2012),h.32

3 M. Karyadi, Kepemimpinan (Leadership), (Bandung: Karya Nusantara 1989),h.22
} 
keberhasilan dari paduan suara di SMA Negeri 9 Manado.

\section{Metode}

Metode yang digunakan dalam penelitian ini adalah metode kualitatif yang bersifat deskriptif. Metode ini digunakan supaya peneliti mendapatkan penjelasan secara rinci mengenai kriteria-kriteria apa saja yang ada pada seorang pelatih yang profesional dan perannya dalam pengembangan kualitas paduan suara di SMA Negeri 9 Manado. Penelitian dilakukan pada bulan Oktober 2019 sampai bulan Juli 2020. Tempat penelitian di SMA Negeri 9 Manado, JL. Jusuf Hasiru, Kleak Kecamatan Malalayang, Kota Manado. Sebagai narasumber penelitian ini adalah pelatih Nine's Voice yaitu Heskiel Manutty, anggota paduan suara yaitu Brigitte, Sisko dan Victor dan Kepala sekolah SMU Negeri 9 Manado, Bapak Meydi Tungkagi, M.Si selaku pembina paduan suara Nine's Voice.

\section{Hasil dan Pembahasan}

Berdasarkan hasil observasi dan wawancara yang dilakukan pada

\footnotetext{
${ }^{4}$ Pusat Musik Liturgi, Membentuk Suara, (Yogyakarta: Pusat Musik Liturgi 2016),h.18
}

paduan suara Nine's Voice di SMA Negeri 9 Manado, peneliti menemukan kriteria-kriteria dan peran dari seorang pelatih yang profesional sesuai dengan teori yang dikemukakan oleh Ali Mudlofir bahwa seorang pendidik yang profesional memiliki tiga aspek yaitu Skill, Knowledge dan Attitude Berikut ini adalah hasil dari temuan penelitian yang diuraikan sebagai berikut :

\section{Kriteria pelatih profesional}

\section{a. Skill}

Dalam tahapan ini, pelatihan yang dilakukan oleh pelatih Nine's Voice yaitu :

1), Pembentukan Vokal.

Pelatih Nine's Voice membentuk standard vokal paduan suara atau choral sound, latihan vokal selalu dilakukan di awal latihan dan biasanya dilakukan selama satu jam. Dalam pembentukan vokal sudah termasuk latihan pernapasan dan vokalisi. Hal ini sesuai dengan apa yang dikemukakan oleh pusat musik liturgi dalam proses membentuk vokal yang baik dan benar. ${ }^{4}$ Pada tahap ini peneliti melihat bahwa pelatih 
melakukan persiapan latihan dengan olah pernapasan. Teknik olah pernapasan dengan cara mengarahkan siswa untuk berdiri pada posisi tegak dan dengan posisi duduk tegak secara rileks. Kemudian mengambil napas dari hidung mengisinya ke paru-paru dan bagian perut setelah itu dikeluarkan dengan berdesis dari mulut secara perlahanIahan $^{5}$. Kemudian peneliti melihat anggota paduan suara melakukan latihan artikulasi huruf baik konsonan maupun vokal.

\section{2). Pengenalan Notasi}

Pada tahap ini, pelatih Nine's Voice melatih latihan membaca notasi pada lagu yang akan dibawakan. Pelatih melatih cara membaca notasi baik notasi angka maupun notasi balok. Pelatih melakukannya secara berkelompok sesuai kelompok suara masing-masing ${ }^{6}$.

\section{3). Latihan Phrasering}

Kemudian kelompok paduan suara melatih teknik phrasering yaitu latihan pemenggalan kalimat. Latihan dipraktekan dengan cara menyanyikan satu frase lagu dengan satu

\footnotetext{
${ }^{5}$ Wawancara dengan Sisko, Juni 2020

${ }^{6}$ Wawancara dengan Heskiel Manutty, Juni 2020

${ }^{7}$ Wawancara dengan Victor Damar, Juni 2020
}

pernapasan. Menurut pelatih latihan pemenggalan kalimat harus dilakukan dengan baik dan benar tujuannya agar pesan dari lagu dapat tersampaikan dengan jelas. Pada tahap ini peneliti melihat seluruh anggota dapat melakukannya tanpa ada kesulitan.

4). Latihan Keterpaduan (Blend)

Dalam tahap selanjutnya pelatih melatih ketepatan nada dari anggota paduan suara ini kemudian pelatih memberikan arahan agar setiap anggota paduan suara tidak menonjolkan kehebatan suara secara individu dari setiap penyanyi agar tidak ada suara yang lebih keras dari suara yang lain ${ }^{7}$.

5). Interpretasi Lagu

Setelah melakukan latihan memperpadukan suara, peneliti mengamati pelatih menjelaskan makna dan maksud dari lagu yang akan dibawakan yaitu Bambu Gila ciptaan Braclyn Picanusa. Lagu ini menceritakan tentang permainan rakyat masyarakat Ambon. Sehingga gaya bernyanyi harus semangat ${ }^{8}$. Pada tahap ini peneliti melihat beberapa anggota paduan suara

\footnotetext{
${ }^{8}$ Wawancara dengan Heskiel Manutty, Juni 2020
} 
belum memahami ekspresi dan penjiwaan disaat membawakan lagu tersebut. Sehingga pelatih harus memberhentikan lagu yang dinyanyikan kemudian menjelaskan kembali secara tegas makna dan penjiwaan lagu tersebut kepada seluruh anggota paduan suara. Terlihat ketegasan pelatih ketika menjelaskan kembali. Karena menurut pelatih hal tersebut sangat penting.

\section{b. Knowledge}

Peneliti melihat bahwa pelatih Nine's Voice memiliki pengetahuan tentang teori dasar musik. Hal ini dapat dilihat dari proses latihan yang diberikan kepada anggota paduan suara tentang notasi balok. Seperti nilai-nilai notasi dan bunyi notasi sesuai dengan tanda kunci yang digunakan ${ }^{9}$. Hal itu dapat dilihat dari bentuk latihan kelompok paduan suara yang mencoba memainkan nilai-nilai notasi dengan cara menepuk tangan dan menyanyikan bunyi nada yang ada pada partitur. Pada bagian ini peneliti melihat anggota paduan suara kesulitan mempraktekan latihan tersebut. Hal tersebut ternyata

\footnotetext{
${ }^{9}$ Wawancara dengan Heskiel Manutty, Juni 2020
}

disebabkan karena latihan ini merupakan sesuatu yang baru bagi mereka. Oleh karena itu pelatih menggunakan strategi pelatihan kelompok jumlah kecil yang terdiri dari lima orang pada masing-masing kelompok. Dengan memanfaatkan tim bidang pelatihan paduan suara yang merupakan anggota senior sebagai tutor sebaya dan diharapkan mampu membantu anggota yang lain bisa membaca notasi balok.

\section{c. Attitude}

Peneliti melihat pelatih ini bukan hanya melatih soal kemampuan anggotanya dalam bernyanyi tetapi juga melatih mereka soal kedisiplinan, tanggung jawab dan kerja sama. Dalam hal ini pelatih memberikan contoh soal kedisiplinan, dimana pelatih selalu hadir 30 menit sebelum latihan dimulai agar anggota paduan suara dapat mengikuti cara kerja dari pelatih $^{10}$. Begitu juga dengan tanggung jawab dari anggota paduan suara, dimana mereka yang ikut dalam pelatihan paduan suara ini untuk dapat menyeimbangkan kegiatan pelatihan dengan kegiatan belajar disekolah

\footnotetext{
${ }^{10}$ Wawancara dengan Brigitte Tumewu, Juni 2020
} 
karena yang mengikuti kegiatan ini harus mempunyai nilai yang baik dalam setiap mata pelajaran disekolah, hal ini dilakukan agar anggota paduan suara dapat bertanggung jawab dalam mengikuti latihan dan juga dalam kegiatan belajar disekolah. Selain itu mereka juga diajarkan untuk dapat bekerja sama antara anggota paduan suara. Walaupun demikian, peneliti masih melihat ada beberapa anggota paduan suara yang datang terlambat. Melihat hal tersebut pelatih langsung bertanya alasan dari anggota yang terlambat dengan tegas dan sopan. Kemudian pelatih memberikan nasehat agar tidak mengulangi kembali.

\section{Aspek pendukung pelatih profesional}

Menurut Ali Mudlofir selain proses latihan teknikal paduan suara seorang pelatih harus didukung dengan 4 Hal seperti dibawah ini :

\section{a. Kompetensi}

Berdasarkan pengamatan
peneliti dari hasil proses latihan
paduan suara Nine's Voice, sosok
pelatih memiliki beberapa kompetensi
seperti kemampuan pedagogi dalam
bidang musik. Hal tersebut dilihat dari
metode pelatihan yang diberikan oleh

pelatih kepada anggota paduan suara. Metode yang digunakan mampu membina anggota paduan suara dapat membaca notasi balok, bernyanyi dengan teknik vokal yang benar dan interpretasi lagu yang tepat. Peneliti melihat pelatih mampu mempraktekan seluruh kompetensi yang harus dimiliki oleh seluruh penyanyi paduan suara seperti olah vokal, membaca notasi, phrasering, keterpaduan, dan interprestasi lagu. Seperti apa yang sudah dipaparkan pada penjelasan sebelumnya.

\section{b. Metode}

Dalam proses pelatihan, peneliti mengamati pelatih Nine's Voice menggunakan beberapa metode yaitu :

1). Metode Linear (drill)

Pelatih menggunakan metode ini untuk melatih anggota paduan suara dalam keterampilan dan musikalitas mereka. Pelatihan yag dilakukan secara berulang-ulang untuk penanaman kebiasaan-kebiasaan dalam bernyanyi. Dalam pembentukan vokal, pengenalan notasi, phrasering dan melatih keterpaduan pelatih selalu mengajarkan secara berulang-ulang.

2). Metode Imitasi 
Dalam melatih paduan suara Nine's Voice, pelatih terlebih dahulu mencontohkan teknik-teknik dalam bernyanyi selanjutnya anggota paduan suara menirukan atau mempraktekan secara langsung teknik-teknik tersebut. 3). Metode Solfegio

Metode ini digunakan pelatih pada saat pengenalan notasi balok sebelum kelompok paduan suara menyanyikan lagu yang ada pada partitur. Seperti memainkan nilai notasi balok dengan tepuk tangan dan menyanyikan nada-nada yang ada dalam partitur tersebut sesuai dengan nilai notasi yang benar.

4). Metode Tutor sebaya

Metode ini dilakukan oleh pelatih dengan cara memberdayakan anggota paduan suara yang memiliki musikalitas lebih baik untuk menjadi tutor bagi sesama anggota paduan suara yang kurang mampu dalam mengikuti materi yang diberikan oleh pelatih. Jadi pelatih menunjuk anggota paduan suara yang memiliki kemampuan lebih untuk dapat membimbing dan mengarahkan anggota paduan suara yang lain yang masih belum dapat mengikuti materi pelatihan yang diberikan oleh pelatih, hal ini bertujuan untuk dapat membantu kinerja dari pelatih serta mengajarkan pelatihan secara mandiri bagi anggota paduan suara.

\section{c. Kepemimpinan}

Peneliti mengamati sosok pelatih memiliki jiwa kepemimpinan yang kuat. Hal ini meliputi dari beberapa sikap yang ditunjukan selama proses latihan, seperti menentukan aturan-aturan yang harus ditaati oleh seluruh anggota paduan suara misalnya tidak boleh terlambat, tidak boleh makan saat latihan. Aturanaturan tersebut peneliti melihat seluruh anggota menaati, dan pelatih tidak sungkan memberikan sanksi kepada seluruh anggota yang melanggarnya.

Selain itu pelatih juga memberi ruang bagi seluruh anggota paduan suara dapat menyuarakan kritik dan saran. Pelatih juga sering meminta pendapat atau berkonsultasi kepada anggota paduan suara terkait hal-hal yang hendak dilaksanakan misalnya penentuan jadwal dan tempat latihan, pemilihan kostum, dan hal-hal personal dari seluruh anggota paduan suara seperti kesulitan anggota paduan suara misalnya jika ada anggota paduan suara yang sakit pelatih berkunjung dan memberikan support moral dan materil. Selain itu pelatih juga sering berkonsultasi kepada pihak 
sekolah berkaitan dengan pengelolaan kegiatan paduan suara. Pelatih juga sering mendelagasikan kepada tim bidang pelatihan untuk melakukan tugas-tugas kepelatihan ketika pelatih tidak bisa hadir. Tujuannya agar proses latihan dapat berjalan, namun pelatih selalu bertanya melalui telepon ataupun whatsapp kepada bidang kepelatihan maupun anggota paduan suara terkait proses latihan yang sudah dilaksanakan.

Peneliti juga melihat pelatih bukan hanya memimpin latihan paduan suara, tetapi pelatih membentuk karakter dari anggota paduan suara. pelatih melatih bagaimana cara berperilaku yang baik di dalam lingkungan sekolah dan pergaulan mereka di luar lingkungan sekolah. Selain itu pelatih juga berperan dalam mengatur manajemen dari paduan suara ini. segala keperluan dan semua kegiatan dari paduan suara ini diatur dan diawasi selalu oleh pelatih.

\section{d. Kreativitas}

Peneliti juga melihat ada beberapa kreativitas yang dilakukan oleh pelatih dalam proses pelatihan. Kreativitas-kreativitas yang diterapkan oleh pelatih antara lain :
1). Pelatih menunjuk senior-senior didalam paduan suara ini yang sudah memiliki kematangan untuk menjadi mentor atau pamong dalam membimbing penyanyi-penyanyi yang belum memiliki kemampuan lebih atau yang masih banyak kekurangan agar mereka dapat menambah kemampuan mereka, dari situ pelatih dapat mengevaluasi sejauh mana perkembangan dari anggota paduan suara ini.

2). Pelatih melakukan latihan di sebuah tempat keramaian misalnya di mall dan di pasar. Pelatih membentuk kelompok-kelompok kecil sesudah itu pelatih mengumpulkan handphone atau semua barang bawaan dari penyanyi kemudian pelatih memberikan sebuah nada atau melodi kepada setiap kelompok-kelompok yang sudah dibentuk, kemudian mereka diberikan kesempatan untuk berkeliling selama satu jam di tempat keramaian kemudian kembali lagi menghadap pelatih untuk menyanyikan kembali nada atau melodi yang sudah diberikan oleh pelatih. Pelatihan ini bertujuan untuk melatih daya ingat dari setiap penyanyi.

3). Pelatih membentuk sebuah kelompok kecil yang terdiri dari 
perwakilan-perwakilan tiap suara, kelompok-kelompok ini diberikan lagu yang sudah dilatih, kemudian pelatih mengadakan lomba dari kelompokkelompok ini, lomba ini dimaksudkan agar mereka mampu melaksanakan latihan secara mandiri dan mampu bekerja sama satu sama lain. hal ini dimaksudkan agar setiap anggota paduan suara mampu benar-benar menguasai setiap lagu yang sudah dilatih.

4). Pelatih mengajak setiap anggota paduan suara untuk ikut melihat konser dari paduan suara yang lain, ini diwajibkan oleh pelatih kepada anggota paduan suara. mereka bukan hanya sekedar menonton tetapi mereka diberikan tugas untuk dapat memberikan evaluasi menurut ukuran mereka tentang penampilan atau cara penyajian lagu dari paduan suara lain yang mereka lihat. ini bertujuan untuk dapat memberikan pembelajaran tambahan dan mereka dapat membandingkan dengan kemampuan mereka sendiri agar dapat memperbaiki dan berlatih lebih giat lagi.

\section{Pembahasan}

Berdasarkan data temuan
penelitian yang peroleh, peneliti
menganalisis bahwa profesionalitas
kepelatihan paduan suara Nine's Voice
didukung dengan kemampuan pelatih
yang mampu melihat kekurangan dan
kelebihan anggota paduan suara serta
metode yang tepat dalam
pengembangan kualitas paduan suara.
Anggota paduan suara yang bukan berlatar belakang musik dan kemampuan teknik dan teori musik yang belum terbentuk mampu dibina oleh pelatih. Pembinaan pelatih dalam membentuk teknik vokal dan wawasan teori musik anggota paduan suara dilakukan dengan metode imitasi yaitu dimana pelatih memberikan contoh langsung seperti bagaimana teknik pernapasan, membaca notasi balok, pengucapan artikulasi yang benar, pemenggalan kalimat lagu, harmonisasi, dan interpretasi lagu. Semuanya itu dipraktekkan kepada seluruh anggota paduan suara sehingga seluruh anggota dapat melihat dan mempraktekkan secara langsung sesuai dengan apa yang dicontohkan oleh pelatih. Hal tersebut dilakukan secara terus menerus (metode drill) hingga setiap anggota menguasai materi yang diajarkan. 
Peneliti melihat bahwa faktor pelatih yang memiliki kemampuan bermusik yang akademisi sangat berpengaruh, yakni secara estetika, komposisi, dan intepretasi. Artinya, pelatih yang memiliki knowledge dan skill cenderung mengajar secara detail dan mampu melihat dan menangani kekurangan atau kelemahan para anggota paduan suara tersebut. Selain itu, peneliti juga melihat bahwa pelatih memiliki relasi yang baik dengan para anggota paduan suara. Hal ini mempermudah proses berjalannya latihan. Pelatih secara tidak langsung dapat lebih mengenal para anggota paduan suara sehingga pelatih lebih mudah dalam mengkomunikasikan atau mengoreksi kesalahan yang ditemukan dalam latihan paduan suara. Selain itu, pelatih juga memilki metode-metode dan kreativitas yang diterapkan dalam proses pelatihan. hal tersebut merupakan pendukung didalam melatih dan membentuk paduan suara yang berkualitas.

Selain itu peneliti menganalisis bahwa pengelolaan sumber daya manusia pada paduan suara Nine's Voice khususnya anggota senior dioptimalkan oleh pelatih untuk membantu proses pembinaan anggota-anggota baru. Disini peneliti melihat ada proses pemuridan yang sudah terbangun. Sehingga kerja pelatih semakin ringan karena pelatih tidak bekerja sendirian melainkan dibantu tim bidang kepelatihan yang dibentuk oleh pelatih. Hal ini sangat signifikan membantu proses pembinaan paduan suara karena pelatih dapat memberikan materimateri yang diajarkan dengan detail, cepat dan tepat melalui tim kepelatihan yang ditugaskan melatih anggota paduan suara dalam kelompok kecil.

Kemudian peneliti mengamati bahwa adanya relasi antara pelatih dengan anggota paduan suara bukan sekedar hubungan antara pelatih dengan murid namun ada ikatan emosi yang sangat erat. Hubungan yang dimaksud adalah hubungan antara kakak dan adik yang terlihat dari sikap empati pelatih kepada seluruh anggota paduan suara misalnya, pelatih mengunjungi anggota paduan suara yang sakit. Selain itu pelatih juga membangun hubungan emosional dengan cara sering mengajak makan bersama seluruh anggota paduan suara. Hal ini peneliti menganalisis bahwa ikatan emosional yang dibangun antara pelatih dengan anggota paduan suara menjadi kekuatan penting bagi pelatih untuk 
memperlancar proses kepelatihan dalam paduan suara Nine's Voice. Ikatan emosional yang kuat akan membentuk rasa percaya diri anggota paduan suara untuk mempelajari materi-materi pembinaan yang diberikan oleh pelatih, karena jarak hubungan awal antara pelatih dengan yang dilatih sudah didekonstruksikan melalui hubungan kakak dan adik.

Peneliti menganalisis pelatih juga memilki kemampuan manajemen organisasi yang baik. Hal tersebut dapat dilihat bagaimana seorang pelatih melibatkan peran kepala sekolah dalam proses pengambilan keputusan-keputusan yang bersifat operasional. Kemudian sebagai pelatih, metode imitasi tidak hanya digunakan pada proses pemberian materi paduan suara namun metode imitasi digunakan oleh pelatih untuk mengajarkan nilai-nilai kedisiplinan dengan cara datang tepat waktu pada proses pelatihan.

Selain itu peneliti juga melihat peran dari seorang pelatih selain melatih sebuah paduan suara, yaitu, pelatih menempatkan diri sebagai seorang pemimpin, kepemimpinan dari pelatih ini ditunjukan bukan sekedar memimpin anggota paduan suara pada tahap pelatihan sampai tahap perlombaan tetapi juga memimpin, membina dan mengarahkan anggotanya didalam kehidupannya bermasyarakat dan didalam lingkungan pendidikan.

Jadi seorang pelatih mempunyai peranan penting dalam perkembangan musikal dan karakter dari anggota paduan suara karena seorang pelatih sebagai pondasi yang kuat dalam mendorong perkembangan kualitas paduan suara dan figur utama dalam kepemimpinan.

\section{Kesimpulan}

Dari hasil penelitian ini yang membahas tentang profesionalitas pelatih dalam pengembangan kualitas paduan suara di SMA Negeri 9 Manado, dapat disimpulkan bahwa, kriteria profesionalitas seorang pelatih paduan suara Nine's Voice bukan saja tentang skill, knowledge dan attitude, namun bagaimana seorang pelatih membangun hubungan emosional antara pelatih dengan anggota menjadi kriteria yang sangat penting. Proses pelatihan tidak akan dapat berjalan dengan lancar apabila anggota paduan suara tidak memilki rasa kepercayaan terhadap pelatih. Kemudian profesionalitas pelatih tidak akan dapat berjalan secara efektif dan efisien 
apabila pelatih bekerja sendirian. Dibutuhkan tim kerja kepelatihan yang solid untuk menunjang kualitas profesionalitas pelatih.

Peran seorang pelatih tidak hanya berfungsi sebagai pengajar namun pelatih yang profesional memliki peran sebagai pengambil keputusan, pembentuk karakter kelompok, menciptakan budaya kelompok dan sebagai pengelola paduan suara. Adapun saran yang dapat disampaikan peneliti kepada pelatih paduan suara agar bisa mempertahankan kinerja kepelatihan bahkan lebih ditingkatkan lagi sehingga kualitas paduan suara agar lebih berkembang lagi dari pencapaian sebelumnya dan kepada anggota paduan suara agar dapat mempertahankan kerja sama dan komitmen yang sudah dibangun sehingga apa yang sudah dicapai selama ini dapat dipertahankan bahkan bisa lebih baik lagi dari apa yang sudah dicapai sebelumnya.

\section{Kepustakaan}

Djohan. 2005. Psikologi Musik, Yogyakarta: Buku Baik.

Mudlofir, Ali, 2012. Pendidik Profesional, Jakarta: PT Raja Grafindo Persada.
Guido Denta Christian, 2016. "Metode Latihan Paduan Suara Universitas Airlangga oleh Yosafat Rannu Leppong", Surabaya, Perpustakaan Jurusan Seni Musik, Fakultas Bahasa dan Seni, Universitas Negeri Surabaya.

Kurniawan, Cessna, 2018. "Peran Pelatih Dalam Pelatihan Paduan Suara Dengan Menggunakan Pendekatan Secara Psikologi di Paduan Suara Voice Of Conservation (VOC) Universitas Negeri Semarang", Skripsi yang diterbitkan,Semarang: Jurusan Seni Drama, Tari dan Musik, Fakultas Bahasa dan Seni, UNNES.

Kurniawan, Aris, 2019. "Pengertian Kualitas”, Jakarta.

Martian, Firsta Kris. 2009. "Pembelajaran Vokal Pada Paduan Suara Adiyuswo Di Gereja Kristen Jawa Limpung Pepanthan Subah Kabupaten Batang", Skripsi yang diterbitkan,Semarang: Jurusan Seni Drama, Tari dan Musik, Fakultas Bahasa.

Karyadi. 1989. Kepemimpinan (Leadership), Bandung: Karya Nusantara.

Moleong, Lexi, 2001. Metodologi Penelitian, Jakarta: PT.Remaja Rosdakarya.

Mohamad, Nasir. 1988. Meteodologi Penelitian, Jakarta: Ghalia Persada Indonesia.

Nawawi, Hamdani. 2003. Kepemimpinan Mengefektifkan 
Organisasi, Yogyakarta: Gajah Mada.

Prastya, Abi Krida. 2012. Proses pembelajaran musik bagi kelompok band Just 4_U di SMA BOPKRI 1 Yogyakarta. Skripsi yang diterbitkan. Yogyakarta. Perpustakaan Jurusan Pendidikan Musik Fakultas Bahasa dan Seni Universitas Negeri Yogyakarta

Pusat Musik Liturgi. 2016. Membentuk Suara. Yogyakarta. PML

Rulam, Ahmadi. Pengantar Pendidikan. Yogyakarta . ArRuzz Media

Sari, Elisa Tresna. 2018. Peningkatan kemampuan solfeggio melalui kegiatan ekstrakurikuler paduan suara di SMP Negeri 1 Sungai Kakap. Diterbitkan oleh Jurusan Pendidikan Bahasa dan Seni, Fakultas Keguruan dan ilmu Pendidikan, Universitas Tanjung Pura Pontianak.

Setiawan, Samhis. 2020. Pengertian Profesional- Etika. Jakarta. 